\title{
Research on Practice Teaching Quality Evaluation System for Engineering Majors
}

\author{
Xiaoqing Yuan ${ }^{1, a^{*}}$, Binghe Ma ${ }^{1, b}$, Shaohui Wang ${ }^{1, c}$ and Ying Zhang ${ }^{1, d}$ \\ ${ }^{1}$ School of Mechanical Engineering, Northwestern Polytechnical University, Xi'an 710072, China \\ ayuan@nwpu.edu.cn, bmabinghe@nwpu.edu.cn, csongwsh@nwpu.edu.cn, \\ dzhangyingcdim@nwpu.edu.cn \\ * The Corresponding Author
}

Keywords: Practice link; Teaching quality; Evaluation system

\begin{abstract}
The paper analyzes influencing factors of present teaching quality of practice link, introduces the thought of the entire process quality control, in view of the different characteristics of the experiment, the practice, the curriculum project, innovative practice and the graduation project, constructs five types of corresponding teaching quality evaluation system by using expert questionnaire survey, exploratory factor method and analytic hierarchy process. And then strengthens the track appraisal and quality control, and forms the trinity practice teaching quality synthetic evaluation operating mechanism which concentrates self-assessment, the student assessment, and the management appraisal and professor committee judgment.
\end{abstract}

\section{Introduction}

With the continuous improvement of the quality requirements of talents training in the society, the role of practice in the cultivation of high-quality and top talents is becoming more and more important, especially for engineering majors in colleges and universities. Most colleges and universities have been paying attention to the quality of theoretical teaching and ignoring the teaching quality of practice [1]. Although in many colleges and universities the construction of practice teaching, experimental teaching center, engineering training center, practical teaching base and innovative practice base has been paid more and more attention, but the assessment and evaluation of the quality teaching of practice, the practice teaching reform are still lack of a guiding evaluation system [2]. With the focus of management of higher education institutions moving down, the construction of practical teaching quality evaluation system that adapts to the characteristics of the professional development and practice teaching in the secondary college is necessary, which not only is conducive to improving students' practice ability and innovation ability, but also can help teachers to carry out practice teaching and promote the construction of practical teaching reform and provide strong support for the cultivation of innovative talents.

\section{Analysis on Influencing Factors of the Practice Teaching Quality of Engineering Majors}

Problems in the Teaching of Practical Links. Especially facing with the professional certification and the country' demand for "double innovation" of talents [3], new professional training programs in engineering strengthen the innovation practice content. Through the study of the quality teaching of practice, there are many problems in the current practice teaching in colleges and universities. As for the practice teaching especially in the importance of innovative practice teaching is insufficiently understudied, practice content and teaching methods are old, and the lack of equipment in practice teaching does not meet the needs of personnel training, the experimental teaching center and practice teaching base management system is not scientific, practice teaching quality guarantee system is not perfect [4]. These problems have direct impacts on the teaching quality and effect of the practice in universities.

Influencing Factors of the Teaching Quality of the Practice Link. There are many influencing factors of practical teaching quality, but it can be summarized as the three aspects: the 
quality of students, teachers and practice environment. Students are the subject of practical teaching activities, and the quality of students includes students' practice motivation and practice quality. As a specific executor of practice teaching process, teaching team is also the implementer of practical teaching activities. The practice environment includes the rich teaching resources, experimental teaching and research equipments, advanced comprehensive practice curriculum system and content. These are the premise and basis of practice teaching, which are also important factors restricting the quality of practice teaching.

Theory and Method of Teaching Quality Evaluation in Practical Link. The key to the quality evaluation of practice teaching is finding out the elements reflecting accurately the change of practical ability, and strengthen control and management of the teaching according to its influence on the quality of practice teaching, so as to ultimately achieve the goal of ensuring the quality of practice teaching. At present, the method of practice teaching evaluation method mostly combine qualitative analysis and quantitative analysis, and try to introduce the management method and digital method to evaluate the teaching quality of practice, such as analytic hierarchy process (AHP), stepwise regression analysis, dynamic process evaluation method, fuzzy mathematics method etc.[5] This paper uses the whole process management theory and AHP to carry out the study of the teaching quality evaluation of the practice link.

\section{Construction of Comprehensive Evaluation System for Teaching Quality in Practical Link}

The essence of constructing the teaching quality evaluation system in practice link is to move forward the focus of teaching quality monitoring and evaluation under the guidance of appropriate teaching quality theory, and track every specific link of teaching process for quality control starting from the formulation of undergraduate training plan. The following is the concrete content of the teaching quality evaluation system in this practice link.

Purpose and Principle of Evaluation. The purpose of practice teaching quality evaluation system is to reflect the actual state of practice teaching quality comprehensively, to grasp the hidden problems and weak links of practice teaching, to adopt positive and effective measures, and to improve the quality of practical teaching, so as to meet the social requirements for students' practical ability through system evaluation on practical teaching links. The comprehensive evaluation of teaching quality in practice links follows the basic principles of combination of scientificity and guidance, combination of simplicity and operability, and combination of process evaluation and finality evaluation.

Design of five Evaluation Index Systems. The teaching quality evaluation system of practice link is closely integrated with undergraduate professional training program, focuses on students' learning effect, teaching conditions, teaching organization and teaching process, and fully mobilizes experiment teachers, teaching managers and relevant experts to participate actively. It is made up of fives index systems: experiment course teaching quality evaluation system, practice teaching quality evaluation system, curriculum design quality evaluation system, innovation practice activity quality evaluation system and graduation project quality evaluation system. all the evaluation index system are applied to determine the connotation of first level index and second level index by expert questionnaire and exploratory impact factor method and according to the relevance between practice and teaching quality, AHP is used to determine the reasonable weight of all levels of indicators. The specific index system is shown in Table 1- Table 5. 
Table 1 Evaluation Index System for Teaching Quality of Experiment Courses

\begin{tabular}{|c|c|c|c|}
\hline First level index A1 & Weight I1 & Second level index a1 & Weight i1 \\
\hline \multirow[b]{2}{*}{$\begin{array}{l}\text { Experiment } \\
\text { preparation }\end{array}$} & \multirow[b]{2}{*}{0.1} & Experimental instruction & 0.5 \\
\hline & & $\begin{array}{c}\text { Preparation of experimental } \\
\text { instruments }\end{array}$ & 0.5 \\
\hline \multirow{3}{*}{$\begin{array}{l}\text { Implementation of } \\
\text { teaching organization }\end{array}$} & \multirow{3}{*}{0.4} & $\begin{array}{l}\text { Content of experimental } \\
\text { teaching }\end{array}$ & 0.4 \\
\hline & & Teaching method & 0.2 \\
\hline & & Process of teaching & 0.4 \\
\hline \multirow[t]{2}{*}{ Experimental report } & \multirow[t]{2}{*}{0.2} & $\begin{array}{c}\text { Experimental records of } \\
\text { Teachers }\end{array}$ & 0.5 \\
\hline & & Student experiment report & 0.5 \\
\hline \multirow{2}{*}{$\begin{array}{c}\text { Teaching } \\
\text { characteristics and } \\
\text { effects }\end{array}$} & \multirow{2}{*}{0.3} & Teaching characteristics & 0.3 \\
\hline & & Teaching effects & 0.7 \\
\hline
\end{tabular}

Table 2 Evaluation Index System for the Quality of Practice Teaching

\begin{tabular}{|c|c|c|c|}
\hline First level index A2 & Weight I2 & Second level index a2 & Weight i2 \\
\hline \multirow{2}{*}{ Practice base } & \multirow{2}{*}{0.2} & Status of practice base & 0.4 \\
\hline & & Environment of practice base & 0.6 \\
\hline \multirow{2}{*}{ Teachers } & \multirow{2}{*}{0.1} & Structure of teacher team & 0.4 \\
\hline & & Academic level of teachers & 0.6 \\
\hline \multirow{2}{*}{$\begin{array}{l}\text { Teaching organization } \\
\text { and management }\end{array}$} & \multirow[b]{2}{*}{0.1} & Practice teaching documents & 0.5 \\
\hline & & $\begin{array}{c}\text { Practice system and } \\
\text { measures }\end{array}$ & 0.5 \\
\hline \multirow{3}{*}{$\begin{array}{l}\text { Process of teaching } \\
\text { implementation }\end{array}$} & \multirow{3}{*}{0.4} & Practice content & 0.4 \\
\hline & & Practice guidance & 0.4 \\
\hline & & Students' practice situation & 0.3 \\
\hline \multirow{2}{*}{ Practice effect } & \multirow{2}{*}{0.2} & Quality of practice & 0.3 \\
\hline & & Comprehensive evaluation & 0.7 \\
\hline
\end{tabular}

Table 3 Evaluation Index System for Teaching Quality of Curriculum Design

\begin{tabular}{cccc}
\hline First level index A3 & $\begin{array}{c}\text { Weight } \\
\text { I3 }\end{array}$ & Second level index a3 & $\begin{array}{c}\text { Weight } \\
\text { i3 }\end{array}$ \\
\hline & \multirow{3}{*}{0.2} & Teaching standard & 0.2 \\
Teaching conditions & \multirow{2}{*}{$\begin{array}{c}\text { Experimental condition } \\
\text { Teaching staff }\end{array}$} & 0.4 \\
& & Teaching goal & 0.4 \\
Process of teaching & \multirow{2}{*}{0.5} & Guidance & 0.2 \\
implementation & \multirow{3}{*}{0.3} & Students' learning situation & 0.3 \\
& Quality of design report & 0.4 \\
Design effect & \multirow{2}{*}{ Comprehensive evaluation } & 0.6 \\
\hline
\end{tabular}

Table 4 Evaluation Index System for Teaching Quality of Innovative Practical Activities

\begin{tabular}{cccc}
\hline First level index A4 & Weight I4 & Second level index a4 & Weight i4 \\
\hline \multirow{2}{*}{ Teaching conditions } & \multirow{3}{*}{0.2} & Teaching standard & 0.2 \\
& & Experimental condition & 0.4 \\
& & Teaching staff & 0.4 \\
Process of teaching & \multirow{2}{*}{0.4} & Teaching goal & 0.2 \\
implementation & & Innovation project & 0.2 \\
& & Guidance & 0.4 \\
innovative practical & \multirow{2}{*}{0.4} & Quality of practice report & 0.2 \\
effect & & Comprehensive evaluation & 0.2 \\
& & & 0.4 \\
\hline
\end{tabular}


Table 5 Index System for Evaluating the Quality of Graduation Design (Thesis)

\begin{tabular}{|c|c|c|c|}
\hline First level index & Second level index & Third level index & Score \\
\hline \multirow{4}{*}{ Teaching goal } & \multirow{2}{*}{$\begin{array}{l}\text { Knowledge } \\
\text { requirements }\end{array}$} & Graduation design task & 2 \\
\hline & & $\begin{array}{l}\text { Knowledge mastery and } \\
\text { Application }\end{array}$ & 2 \\
\hline & \multirow{2}{*}{$\begin{array}{l}\text { Ability } \\
\text { requirements }\end{array}$} & Standard of ability training & 2 \\
\hline & & Measures and methods & 2 \\
\hline \multirow{8}{*}{$\begin{array}{l}\text { Teaching } \\
\text { conditions }\end{array}$} & \multirow{2}{*}{ Teaching staff } & Teacher structure & 2 \\
\hline & & Academic level & 4 \\
\hline & \multirow[b]{2}{*}{$\begin{array}{l}\text { Teaching } \\
\text { documents }\end{array}$} & Rules and regulations & 2 \\
\hline & & $\begin{array}{l}\text { Graduation design task } \\
\text { book }\end{array}$ & 2 \\
\hline & \multirow{4}{*}{ Material guarantee } & Experimental equipment & 1 \\
\hline & & Experimental environment & 1 \\
\hline & & Graduation funds & 1 \\
\hline & & Topic type & 2 \\
\hline \multirow{11}{*}{$\begin{array}{l}\text { The process of } \\
\text { teaching }\end{array}$} & \multirow{3}{*}{ Topic selection } & Meet the requirements & 3 \\
\hline & & Teaching attitude & 3 \\
\hline & & Guidance method & 3 \\
\hline & \multirow{3}{*}{ Student status } & Progress implementation & 3 \\
\hline & & Independent work situation & 2 \\
\hline & & The style of study & 2 \\
\hline & \multirow{3}{*}{ Defense score } & Organization arrangement & 2 \\
\hline & & Grading standard & 2 \\
\hline & & Reviews & 2 \\
\hline & \multirow{2}{*}{ Summary } & Summary & 2 \\
\hline & & File placing & 2 \\
\hline \multirow{9}{*}{ Teaching effect } & \multirow{6}{*}{ Ability level } & Problem-solving ability & 8 \\
\hline & & Design computing ability & 3 \\
\hline & & $\begin{array}{l}\text { Computer application } \\
\text { ability }\end{array}$ & 3 \\
\hline & & Literature retrieval ability & 3 \\
\hline & & $\begin{array}{l}\text { Foreign language } \\
\text { translation ability }\end{array}$ & 3 \\
\hline & & $\begin{array}{l}\text { Independent expressive } \\
\text { ability }\end{array}$ & 3 \\
\hline & \multirow{2}{*}{$\begin{array}{l}\text { Quality of } \\
\text { graduation design }\end{array}$} & Quality of paper writing & 10 \\
\hline & & $\begin{array}{c}\text { Quality or object of } \\
\text { drawings }\end{array}$ & 10 \\
\hline & Creativity & Innovation in design & 7 \\
\hline
\end{tabular}

Operating Mechanism of the Teaching Quality Evaluation System in the Practice Link. The comprehensive teaching quality evaluation system in practice link takes experimental teaching, practice teaching, curriculum design, innovative practice and graduation design practice teaching as the evaluation object, and it adopted the operation mechanism which is the combination of self-evaluation, student evaluation, teaching office evaluation and the approval of teaching committee. The specific operation steps are as follows: The first step is teachers' self-evaluation. Teachers should fill out the self-assessment form of practice courses, and evaluate the specific situation of individual courses. The second step is student evaluation. Students from different majors were randomly allocated to twenty students. The questionnaire on the teaching practice of each professional session was conducted. The third step is teaching office evaluation. The college will organize experts from the supervision group. Through on-site checks, materials inspection, document examination, students' seminars, teachers' seminars and students' skills test, we can conduct a comprehensive evaluation of the professional practice teaching, analyze the existing 
problems links to get an evaluation summary report and evaluation results, and put forward rectification opinions. The last step is the validation of teaching committee of the professor committee. The committee summarizes the self-evaluation, student evaluation, teaching office evaluation conclusion and rectification opinions, approves the summary report, and puts forward the feedback to all teaching departments and teachers. According to the opinions of the teaching committee, teaching departments make the rectification plan, improve the management system and guarantee measures, and gradually solve the key problems affecting the quality of practice teaching.

\section{Summary}

The evaluation of teaching quality in practice link is a comprehensive evaluation of the implementation of the training program and the whole teaching process, the reform and innovation of experimental teachers, the comprehensive quality of students, and the cultivation of innovative thinking and ability. The comprehensive teaching quality evaluation system in the practical link can reflect the actual state of the teaching quality of various professional practice links in a more comprehensive way, find out the hidden problems and weak links in every link of practice teaching, guide the reform of practice teaching, strengthen the importance of teachers and students to the quality of teaching in practice, mobilize the enthusiasm and sense of responsibility of the teachers in the practice of teaching. It has a strong impetus to improve the teaching quality of the practical link, and provides a strong support for the cultivation of high-quality top talent.

\section{Reference}

[1] Wang Tongkun, Ma Ailin. Analysis of influencing factors and guarantee system of higher education and teaching quality. Journal of Hebei Normal University of Science and Technology: Social Science Edition, 3 (2007) 7-11.

[2] Jin Huimin, Liu Ziping, Wang Qing and so on. Analysis of the influencing factors and Countermeasures of teaching quality. Medical Education Exploration, 7 (2007) 600-601.

[3] Ai Hong. The construction of the quality evaluation system for the practical education of excellent en gineers. Heilongjiang High Education Research, 10(2014)61-63.

[4] Huang Rongsheng. On the basic problems of higher education quality. Chinese Higher Education Research, 4(2012)5-9.

[5] Li Luping, Zhang Yonghua, Zhou Jian, Fu Xiangling. An analysis of the multi-dimensional concept of practical education in Colleges and universities. Chinese University Teaching, 11(2011)83-86. 